DOMINIQUE ANXo, THOMAS ERICSON \& ANNIE JOLIVET 2012-3

\title{
Working longer in European countries: underestimated and unexpected effects ${ }^{1}$
}

${ }^{1}$ Forthcoming in the International Journal of Manpower, 2012

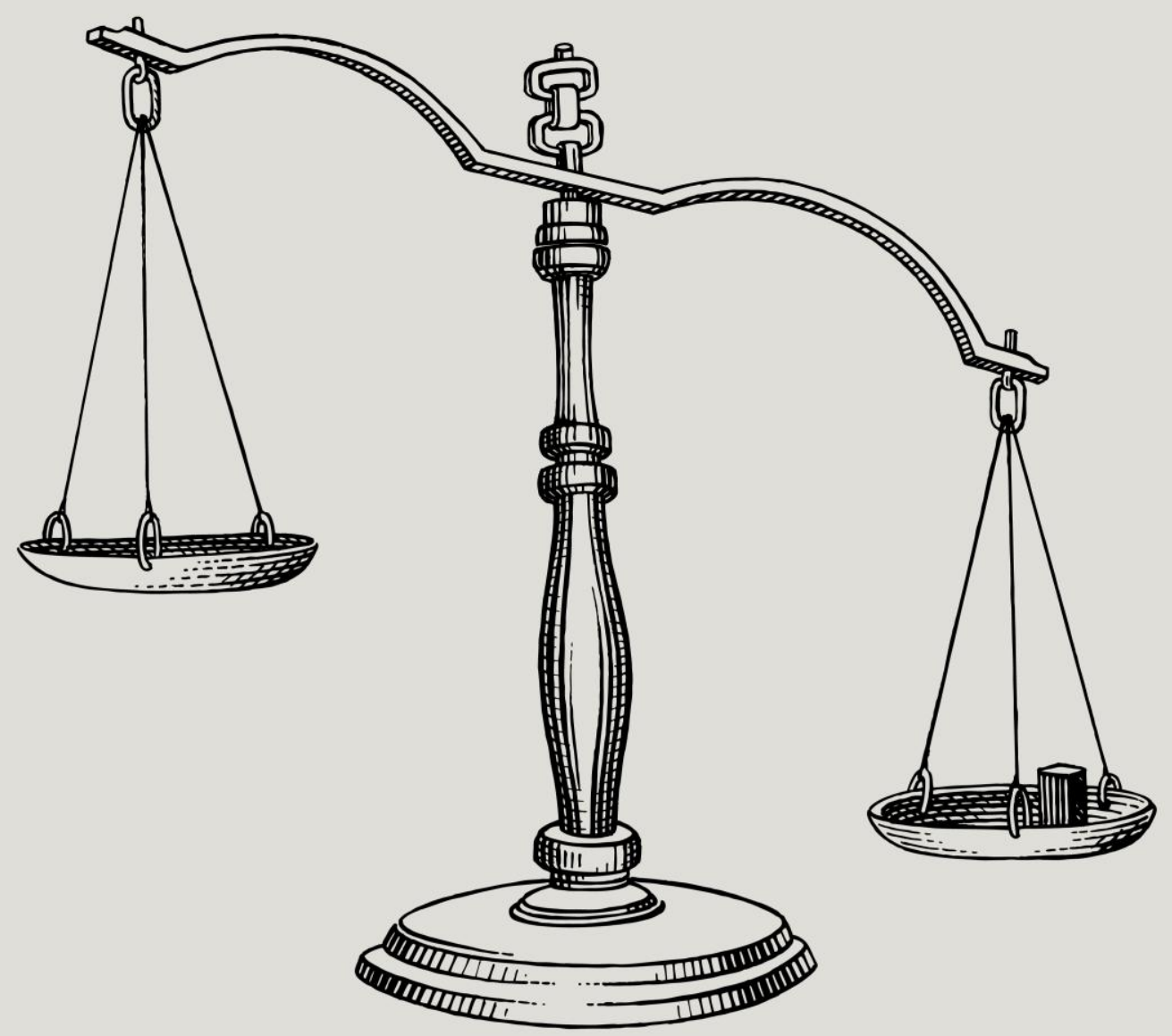




\section{Abstract}

\section{Purpose}

The main objective of this paper is to analyse the main evolutions and the current situation of the 50-74 years old on the labour market in eight European countries (Denmark France, Germany, Italy, The Netherlands, Sweden, Poland and the United Kingdom). Based on a cross-country comparative approach, this overview draws on detailed analysis of the situation of older workers and public policies in each of the selected countries but also on a wide range of available studies and statistics on employment and welfare outcomes. Our eight selected countries display similarities: a ushaped pattern of employment rates of older workers (55-64 years old) over the last 40 years, with an increase since mid 1990s, the later exit of higher educated workers and the higher prevalence of non-standard employment contracts among older workers. On the other hand, considerable disparities can be observed regarding the gender gap in employment rate, current employment rates, self-employment and part-time employment among older workers.

\section{Contact information}

Dominique Anxo

Linnaeus University

Centre for Labour market and Discrimination Studies

SE-351 95 Växjö

dominique.anxo@lnu.se

Thomas Ericson

Linnaeus University

Centre for Labour market and Discrimination Studies

SE-351 95 Växjö

thomas.ericson@lnu.se

Annie Jolivet

Centre d Etude de l'Emploi (CEE)

Studies Centre on Age and Populations at Work (CREAPT)

Paris 


\section{Introduction}

From the early 1970s to the mid 1990s in most advanced economies there was a clear trend for people, or at least men, to withdraw earlier and earlier from the labour market, reflecting both lowering of standard pension ages and, in several European Union member states, a massive use of early retirement schemes or alternative exit routes such as disability pensions or unemployment benefits. From 1997 and especially from 2001, increasing older workers employment rate has been set as a priority in the EU, with the main objective of insuring the long term financial stability of pension systems. During the last decade, a set of measures aiming at increasing the 55-64 years old employment rate and at lengthening working life were launched in a growing number of EU countries. What does a longer working life implies in terms of employment patterns: a marginal adjustment or strong structural changes? What consequences are the current and planned reforms expected to have on the overall situation of this age group?

In this article, we argue that increasing employment rates of older people should not be reduced to only an issue about safeguarding financial stability of the pension systems. There are several socio-economic consequences of longer working life at old age that deserve more attention. Four central aspects are highlighted in this article: Firstly, there are strong reasons to believe that later retirements result in increasing inequalities between older workers. This is because new pension systems are designed to mirror lifetime earnings, which may affect individuals' income during retirement quite differently, depending on the distribution of risks concerning career and employment disruptions between gender and socio-economic groups. Secondly, as alternative exit routes to early retirement gradually have been or will be restricted, sustainable working conditions for older workers will have to appear on the policy agenda. Thirdly, exit from the labour force at old age is gradually to be governed by workers' individual decisions. It is no longer taken for granted that older workers' employment contract ends by mandatory retirement or a pension agreement between the employer and the employee. When the employers lose control over exit decisions, their hiring and retentions of older workers will be accompanied by uncertainty about how long the employees will stay and how productive they will be. As a result, it is possible that age discrimination will be increasing in the future. And finally, unpaid activities will be affected by more paid employment. In particular, informal care of older relatives may cause a double burden for older female workers.

These considerations are based on a cross comparative research project (ASPA), where we analyse the situation of older workers on the labour market and assess the consequences of the pension reforms already implemented in eight EU-countries: Denmark, France, Germany, Italy, the Netherlands, Poland and Sweden. It is demonstrated that our considerations above are generally valid in all eight countries, despite the countries' diversities in employment rates of older workers and public policies towards them. Hence, the increasing inequalities between groups of older workers, the need for sustainable working conditions, increasing risks of age discrimination, and impact of care of older relatives, deserve further research.

First we set the scene by drawing attention to the co-existence of diversities and similarities of labour market features for older workers in our eight selected countries (section 1). We then discuss the potential impacts of the pensions reforms in terms of growing inequalities (section 2), work environments and sustainable work (section 3), 
increasing age-discrimination (section 4), and consequences of unpaid activities (section 5). Conclusions and a discussion about policy implications are found in the final section.

\section{Trends of older workers' employment rate: still a maximum of diversity in a minimum of space}

Prolonging working life raises several questions regarding the evolution of the employment rate and employment patterns at older ages. Various patterns exist: prolongation of paid employment with the current employer or self employment, either part-time or full-time, redeployment to another employer, paid employment with a reduced working time combined with pension, transition to self employment, creation of company. The main objective of this section is to identify the main disparities and similarities in older workers labour market positions within and across our eight selected countries.

From 1971 to 1995 , the decline in employment rates was particularly marked for older men (55-64 years old) in France (-34.5 percentage points), The Netherlands (-30 percentage points) but also in Germany ( -28.9 percentage points) and the UK (-23.1 percentage points). Increases in employment rates since 1995 have only partially reversed these falls (Table 1). The trend reversal in this century can be attributed primarily to the various pension reforms initiated in most of our selected countries over the last decade aimed at increasing financial incentives to postpone retirement and to the limiting or closing of national pre-retirement programmes or alternative routes to early withdrawal. It is also due to a global increase in employment, due to economic growth. This trend has been reversed as soon as the mid nineties for some countries, at the turn of the century for others. The trend reversal in this century can be attributed primarily to the various pension reforms initiated in most of our selected countries over the last decade aimed at increasing financial incentives to postpone retirement and to the limiting or closing of national pre-retirement programmes or alternative routes to early withdrawal. It is also due to a global increase in employment, due to economic growth. If we also take into account older women's employment rates, we find three countries are far from reaching the EU target of $50 \%$ : France, Italy and Poland - failing to reach even 40 per cent in 2009. In the remaining countries employment rates of older workers (55-64 years old) are significantly above the 50 per cent target. The Nordic countries as well as the UK display the highest employment rates among elderly workers (reaching even 70 percent in Sweden).

In most of the eight selected countries, women have contributed more than men to the increase of the employment rate. The gender employment gap among senior workers is the lowest in France and Sweden, despite large differences between these countries in overall older worker employment rates. On the contrary, it is particularly pronounced in Italy, Poland and the Netherlands (around 20 percentage points). These large gender employment gaps reflect women's general problems of integrating into employment at earlier stages of the life course, lower activity rate in some countries, lack of opportunities to re-enter at later ages (Anxo et al., 2006; Anxo and Erhel, 2008; Anxo et $a l ., 2010)$. In Poland and the UK, lower statutory retirement ages still apply to women allowing them to retire in principle on a full pension benefit before the age of 65 , but the statutory retirement age (State pension age) in the UK is planned to be 65 years old for 
both men and women, the equalisation of pension age starting in 2010 and will be completed by 2020 (Casey and Lindley, 2011).

Table 1: Trends in employment rates of older workers (men 55-64 years old, 1971 2009) employment rate (55-64 years old, all and women 2009) and gender gap 2009.

\begin{tabular}{|c|c|c|c|c|c|c|c|c|c|c|}
\hline Country & 1971 & 1985 & 1995 & 2000 & 2009 & $\begin{array}{l}\text { Variation } \\
\text { in \% } \\
\text { points } \\
1971- \\
2000\end{array}$ & $\begin{array}{l}\text { Variation } \\
2000- \\
2009 \text { in } \\
\% \text { points }\end{array}$ & $\begin{array}{l}\text { All } \\
2009\end{array}$ & $\begin{array}{l}\text { Women } \\
2009\end{array}$ & $\begin{array}{l}\text { Gender } \\
\text { Gap } \\
2009\end{array}$ \\
\hline Denmark & n.a & 62.0 & 63.2 & 61.9 & 64.1 & n.a & +2.2 & 57.5 & 50.9 & 13.2 \\
\hline Germany & 77.1 & 53.6 & 48.2 & 48.2 & 63.9 & -28.9 & +15.7 & 56.2 & 48.7 & 15.2 \\
\hline France & 73.C & 46.8 & 38.4 & 38.5 & 41.4 & -34.5 & +2.9 & 38.9 & 36.6 & 4.8 \\
\hline Italy & 46.5 & 37.5 & 42.3 & 40.3 & 46.7 & -6.2 & +6.4 & 35.7 & 25.4 & 21.3 \\
\hline Netherlands & 79.9 & 47.0 & 39.9 & 49.9 & 65.4 & -30.0 & +15.5 & 55.1 & 44.7 & 20.7 \\
\hline Poland & n.a & n.a & 44.5 & 37.4 & 44.3 & n.a & +6.9 & 32.3 & 21.9 & 22.4 \\
\hline Sweden & 82.8 & 73.2 & 64.4 & 67.8 & 73.2 & -15.0 & +5.4 & 70.0 & 66.7 & 6.5 \\
\hline UK & 82.9 & 62.3 & 56.1 & 59.8 & 66.2 & -23.1 & +6.4 & 57.5 & 49.2 & 17.0 \\
\hline
\end{tabular}

Source: Eurostat (2010), and Guillemard (2010).

The UK and Sweden are often taken as representing polar types of welfare capitalism and indeed their relatively high employment rates among senior workers reflect the different welfare systems. The lower degree of de-commodification, in particular the relatively low replacement rate of the statutory/mandatory pension schemes and the uneven coverage of occupational pensions in the UK create strong incentives for working longer. In contrast, in the Nordic countries it is the higher degree of de-commodification and the high level of public spending that requires a high level of employment over the whole life course and at the end of the job career for both men and women. Obviously this later exit is also encouraged by the age culture or norms embedded in Sweden's human resource management practices, such as less prevalent age discrimination, relatively flat ageearnings profiles and the financial incentives to postpone retirement in the new Swedish pension system (see section 3 below). The long-run trends in exit ages do not only reflect the impact of changing policy regimes but also the effect of rising living standards and the related increased demand for leisure ${ }^{1}$. Other determinants, such as demand side factors and social norms play an important role in driving down the participation rates of elderly workers. Under technological and industrial restructuring, the demand for lowskilled older workers has declined, leading to more effectively involuntary exits.

As we turn to analyse the current (2011) employment rates of older workers, three groups of countries might be distinguished: France, Italy and Poland with employment rates around 32-39 per cent, Denmark, Germany, Netherlands and the UK with 55-58 per cent, and finally Sweden where employment rate for elderly workers reaches 70 per cent (Figure 1). The employment rate of elderly workers (65-69 years old) remains far from the employment rate of the preceding age group, even for countries with a high senior employment rate.

\footnotetext{
${ }^{1}$ According to OECD (2003), past changes in financial incentives (implicit tax rates on continued work) and standard retirement ages explain only a third of the trend decline in older males' employment rates in OECD countries over the last three decades.
} 
Figure 1: Employment rates, 55-64 and 65-69 years old, 2011.

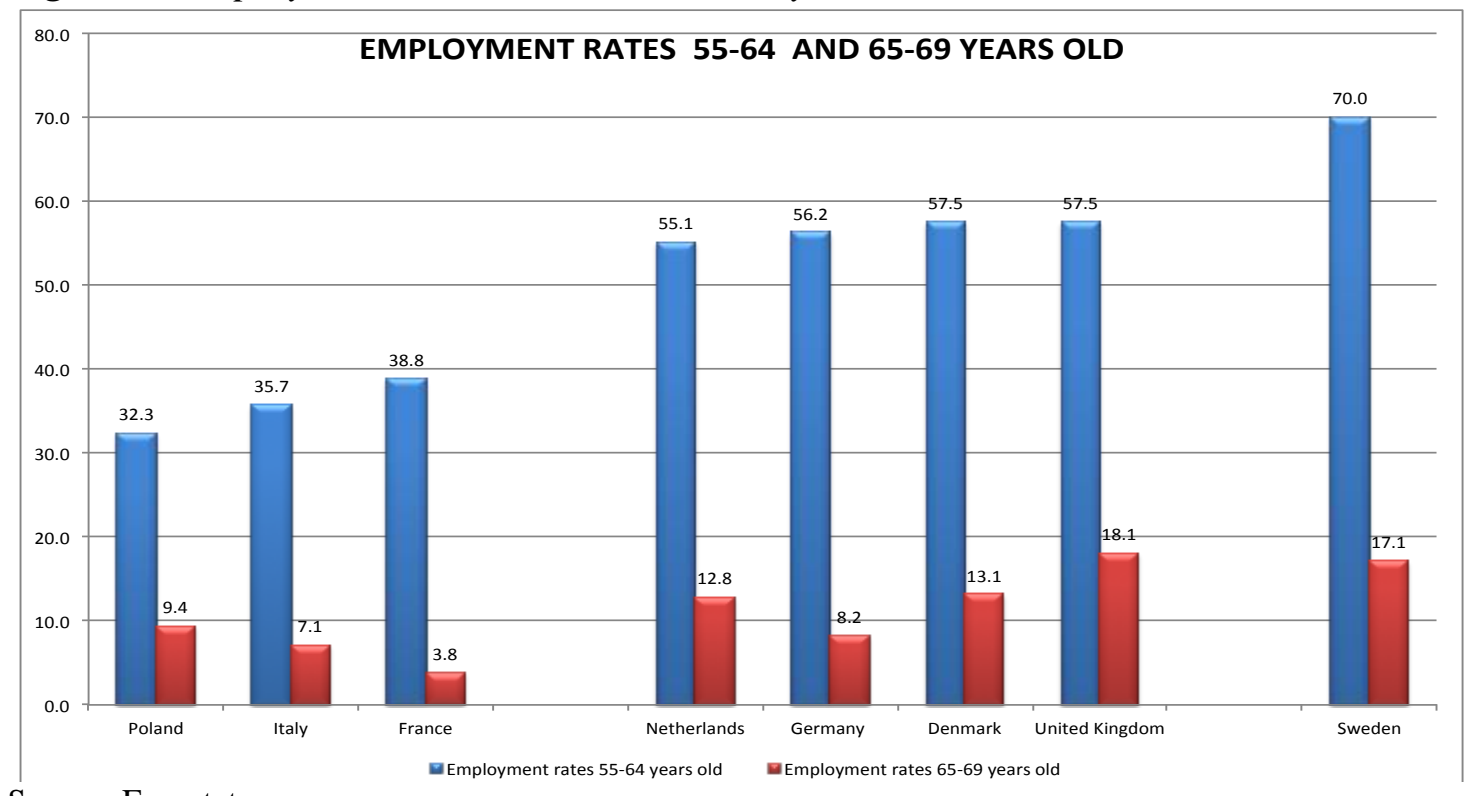

Source: Eurostat

A first salient feature appears as we focus on employment rates for elderly workers according to their levels of educational attainments. It becomes clear that higher schooling generally is associated with considerably higher employment probabilities at old age (Table 2), as employment rates are significantly higher for people belonging to the level of education ISCED 5-6 (University degree or similar) than level 3-4 (College degree) and level 0-2 (Elementary school).

Table 2: Employment rates of older workers (55-64 years old, 2009) by educational attainment.

\begin{tabular}{lccc}
\hline & $\begin{array}{c}\text { ISCED 5-6 } \\
\text { (University) }\end{array}$ & $\begin{array}{c}\text { ISCED 3-4 } \\
\text { (College) }\end{array}$ & $\begin{array}{c}\text { ISCED 1-2 } \\
\text { (Elementary) }\end{array}$ \\
\hline Denmark & 70.3 & 58.6 & 46.0 \\
France & 55.0 & 40.6 & 30.9 \\
Germany & 71.8 & 54.5 & 39.1 \\
Italy & 65.6 & 47.9 & 25.8 \\
Netherlands & 69.3 & 57.7 & 42.3 \\
Poland & 56.2 & 31.2 & 22.3 \\
Sweden & 81.6 & 69.8 & 61.0 \\
UK & 66.2 & 63.0 & 43.5 \\
\hline
\end{tabular}

Source: Eurostat (2011)

There are several reasons why highly educated individuals often stay longer on the labour market. They are less exposed to work injuries and unhealthy working conditions, they participate more often in further training and life-long learning, they are less exposed to selective redundancy processes in the manufacturing sectors, they enter the labour market later than lower educated workers, and they may also be able to balance their workingtime and leisure in a way that improves their chances to stay on the labour market at old age. However, it is clear that countries which have a high employment rate for older 
workers also employ more workers with the lowest levels of educational attainment (Cornilleau et al., 2007).

The persistently higher employment rates of highly educated older workers create both opportunities and challenges. An increasing average level of education in the workforce has resulted in increasing employment rates of older citizens. In particular, the closing up of employment rates between men and women aged 55-64 seems to be a result of women's increased investment in education (in particular in Italy, see Checcucci et al., 2011 and in the Netherland see Schippers et al., 2011). A great challenge, however, is to include lower educated social groups, by increasing their further training and by improving the matching process between individual skill and job requirement. The matching of workers' skills and job requirements is pointed out as a particular critical issue in Poland, even for the highly educated groups of senior workers, as the transition from the socialistic political and economic system to a liberal market economy and democracy has resulted in new job requirements and employer demand for qualifications that were not previously asked for (Perek-Bialas and Turek, 2011).

A central question is to assess to what extent non-standard employment contracts (selfemployment, temporary employment, part-time employment) are more common among elderly workers. All our selected countries display an increasing share of atypical employment forms as workers reach the ages above the standard age of retirement (Table 3). Especially in Italy and Poland, there are high shares of self-employed workers (in Italy over 30 percent of male workers 55-64 years, and over 70 percent of male workers 65 years and older). Self-employment seems often to be a bridge between ordinary employment and retirement, as self-employees often work part-time and the workers continue to work for their former employer or in their own firm. It might also be the case that self-employees have a higher propensity to continue to work after 65 , because they are liquidity constrained and have less generous pension conditions, or simply because their work is a central part of their way of life. In a similar pattern as for the self-employees, the share of workers who are temporary employed increases significantly at 65 years and above. Temporary employment is largely connected to transitional labour markets when young people enter the labour market and older peoples are in the process of leaving the labour market. Labour market regulations are central for explaining the general prevalence of temporary employment as well as to what extent it is common among older workers. Large divergence exists in employment protection for elderly workers across our selected countries. Among the liberal regimes, Denmark is characterized by a relatively weak employment protection and fairly liberal hiring and firing practices. In some segments of the Danish labour market manual workers can be fired from one hour to the next or from one day to another (Jensen and Madsen, 2011). At the other end of the spectrum, older workers in Germany benefit from high employment protection and job security due to preferential collective agreement regulations and a higher share of open-ended contracts than younger workers. In Sweden also the application of a seniority principle (last-in first out, LIFO) regarding dismissal appears also as to be a good instrument to protect older workers during recession. However, at the standard age of retirement, employment law in general no longer protects older workers. Employees in the UK may request to work beyond the age of 65, but employers do not have to acquiesce to this request, and they do not have to justify their refusal. Moreover, their support is working beyond that age seems limited (van Dalen et al., 2010). Similar constructions can be found in Sweden, where the employer can terminate the employment contract with one month notice, without any legally binding reasons when the employee turns 67 years old. 
Table 3: Employment rates of older workers (55-64 and 65- years old, 2009), selfemployees, temporary employment, part-time employment

\section{Self-employment Temporary employment $\quad$ Part-time} employment

\begin{tabular}{lcccccc}
\hline & $55-64$ & $65+$ & $55-64$ & $65+$ & $55-64$ & $65+$ \\
\hline Denmark & 7.2 & 19.1 & 3.5 & 9.5 & 27.7 & 64.3 \\
France & 9.2 & 25.2 & 8.0 & 31.2 & 21.2 & 52.2 \\
Germany & 7.5 & 22.6 & 4.5 & 8.0 & 27.7 & 68.5 \\
Italy & 21.6 & 51.5 & 5.5 & 13.3 & 10.9 & 24.9 \\
Netherlands & 14.2 & 43.7 & 6.9 & 46.3 & 49.8 & 83.2 \\
Poland & 20.2 & 41.8 & 22.0 & 38.6 & 18.6 & 57.6 \\
Sweden & 9.0 & 37.3 & 5.7 & 38.5 & 28.3 & 70.3 \\
UK & 14.5 & 27.2 & 4.8 & 14.8 & 31.5 & 67.7 \\
\hline
\end{tabular}

Source: Eurostat (2011)

The incidence of part-time employment is often a reflection of the different national work-life balance strategies, and mirrors the extent to which mothers combine employment and family commitments. In countries where marriage and children is still associated with a drop in employment rates, the incidence of female part-time employment is consequently lower (Italy, Poland) than in countries where part-time employment remains a way for mothers to combine employment and family commitments (Sweden, Holland, Germany, Denmark). Part-time employment can also be an indication of weak labour market attachment. Globally, part-time employment is equally prevalent for women in the age group 50-64 as for women in prime age (25-49 years), and then increases further for 65 years and above. A survey conducted in Germany indicated that around 80 percent of women above 45 years who were working part-time did so voluntarily (Alexandrowicz and Frerichs, 2011). Furthermore, a large share of women above 45 years stated "personal or family obligations" as reasons for their part-time work, which could be an indication of insufficient supply of public subsidized childcare and eldercare.

We can thus conclude that our eight selected countries display both similarities and differences in terms of older workers employment rates, educational levels and prevalence of non-standard employment contracts. Among the common features, employment rates of older workers (55-64 years old) over the last 40 years display a ushaped pattern where early exit of older workers was motivated by structural changes on the labour market and increasing unemployment. The increase since mid 1990s can be derived from increased female labour force and reformed pension policies. It is striking to see that high education is an effective protection against early exits from work in all eight countries. Consequently, increasing employment rates of older workers need to focus on how to keep lower educated workers in their jobs. Furthermore, non-standard employment contracts are more prevalent among older workers, which can both reflect a desirable flexibility of working time and job contents as well as weakening of job security and attachment to the labour market. On the other hand, considerable disparities can also be observed between our selected countries. The gender gap in employment rate is pronounced in Italy, the Netherlands, and Poland, while the female employment rate is close to male employment rates in France and Sweden. In terms of current employment rates, we can distinguish three groups. France, Italy and Poland show employment rates 
below 40 per cent of population 55-64 years old while Sweden reaches 70 per cent. In between stand Denmark, Germany, the Netherlands and the United Kingdom. Furthermore, Italy and Poland reveal higher rates of self-employment of older workers while part-time employment is lower than in other countries, where part-time employment remains a way for mothers to combine employment and family commitments. Disparities in employment patterns can thus be explained by different employment patterns during prime age (25-49 year old) as well as public policies that support female work or regulations of employment contracts.

\section{Potential impacts of the pension reforms: growing inequalities?}

\subsection{Recent pension reforms}

Over the last two decades, all our selected countries have undertaken pension reforms (OECD, 2008). These reforms have included, among other things, increases in retirement/entitlement ages and changes in eligibility criteria, a strengthening of the link between pensions benefit levels and earnings, a lowering of replacement rates for new entrants as well as a greater role played by private pension schemes in providing incomes in old age. Public early retirement schemes have been severely restricted and sometimes closed to new entrants (Germany, Poland, Sweden).

When these reforms are completed, most countries will have a standard legal retirement age of 65 years, 67 or more in Germany, and the United Kingdom. In 2010, France has finally leveled off the minimum age for a full pension to 62. However, effective retirement ages are still on average even lower than the current statutory pension ages, except for men in Sweden (Table 4). In France the effective retirement age is even below 60 independently of gender and below 60 years for women in Poland, indicating the still large-scale use of early retirement schemes or other equivalent benefit-based exit routes such as unemployment insurance in these two countries. The decline in the effective retirement age, evident in most of our selected countries from 1970, has been reversed at the turn of the new century but the withdrawal age is still significantly younger than in the 1960s and 1970s ${ }^{2}$. This decline in the effective exit age has been common for both men and women ${ }^{3}$. The narrowing of gender gaps in exit ages over the last 40 years implies some form of convergence in exit behaviour of men and women but in practice, if retirement is to facilitate complementary leisure for couples, women are likely to exit earlier as the male spouse is still on average a few years older.

\footnotetext{
${ }^{2}$ The effective mean age of retirement during the period 1965-70 was for men 68.3 years in Denmark, 67.6 in France, 65.9 in Italy, 66,6 in the Netherlands 73,6 in Poland 67.9 in Sweden and 67.7 in the UK. The corresponding figures for women were 66,0 years in Denmark 68.2 in France, 62.1 in Italy, 66,7 in the Netherlands72,2 in Poland, 66.6 in Sweden and 65.7 in the UK (OECD 2009b).

${ }^{3}$ Although the exit age is effectively only calculated for those in employment from age 40 onwards which applied to smaller shares of each female cohort in earlier decades.
} 
Table 4: Early, Standard and Mean Age of Retirement Breakdown by sex

\begin{tabular}{llllll}
\hline & $\begin{array}{c}\text { Early Age of } \\
\text { Entitlement }\end{array}$ & \multicolumn{2}{c}{$\begin{array}{c}\text { Standard/official Age } \\
\text { of Retirement }\end{array}$} & $\begin{array}{l}\text { Effective Mean Age } \\
\text { of Exit** }\end{array}$ \\
& & Men & Women & Men & Women \\
Denmark & 65 & 65 & 65 & 63,5 & 61,3 \\
France & 60 & 60 & 60 & 58.7 & 59.5 \\
Germany & 63 & $67 * *$ & $67 * *$ & 62.1 & 61.0 \\
Italy & $57 / 56$ & 65 & 65 & 60.8 & 60.8 \\
Netherlands & 60 & 65 & 65 & 61.6 & 61,3 \\
Poland & $65 / 60$ & 65 & 60 & 61.4 & 57.7 \\
Sweden & 61 & 65 & 65 & 65.7 & 62.9 \\
UK & $65 / 60$ & $65^{* * *}$ & $60^{* * *}$ & 63.2 & 61.9 \\
\hline
\end{tabular}

* The average effective age of retirement is defined as the average age of exit from the labour force during a 5-year period. Labour force (net) exits are estimated by taking the difference in the participation rate for each 5-year age group (40 and over) at the beginning of the period and the rate for the corresponding age group aged 5-years older at the end of the period. The official age corresponds to the age at which a pension can be received irrespective of whether a worker has a long insurance record of years of contributions (OECD 2009a).

** The standard retirement age in Germany has been raised to 67 years old in 2007. The change will take effect from 2012 and fully implemented by 2029.

*** In the UK the state retirement age will be 65 years for both men and women in 2020 and is set to increase to 68 by 2050 . For France, workers can retire at age 62 with 41.5 years of contributions; for Italy, at 57 (56 for manual workers) with 35 years of contributions.

Source: OECD 2003, 2009a and 2009b for the effective mean age of exit.

According to a recent study (OECD, 2008), the consequence of pension reforms on different levels of earnings varies between our selected countries. This adds to the inequalities in exit age noticed before. In France and Sweden, for example, as a consequence of the pension reform, pension benefits for average earners are expected to drop by around $20 \%$. However, low earners should expect only a slightly smaller pension than previously, implying a reduction of the dispersion of income among retirees. While benefits of average earners is expected to remain unchanged in the United Kingdom, low earners can expect a higher net replacement rate because of the new pension credit and second state pension. Regarding France, previous studies have already shown that the reforms of the pension systems in 1993 and 2003 have contributed, for the generations concerned, to a lower level of pensions. In Italy, the reduction in benefits for low earners is estimated to be larger than for people on average pay, increasing the risk of poverty in retirement for people with low earnings, who also tend to have incomplete contribution records. The German pension reform with its "across-the-board" reduction of benefits entails a proportional decrease in benefits, broadly similar for low and average earners. A future rise in old-age poverty is also a concern in Germany, where the across-the-board undifferentiated cuts in public pensions may be considered regressive. With future lower public pensions, there is a risk that a larger share of retirees will be reliant on social 
benefits or other social transfers. While Germany's pension reforms might have achieved financial sustainability, it is doubtful whether the drop in the value of the statutory pensions will be counterbalanced by supplementary occupational and private pensions, implying that a stronger safety-net will be needed to avoid resurgence in old-age poverty.

\subsection{A stronger life-course perspective}

The extension of contributing periods (France, Poland) as well as the introduction of lifetime income principles (Italy, Sweden) may affect individuals' income during retirement quite differently, depending on the distribution of risks concerning career and employment disruptions between gender and socio-economic groups. The introduction of lifetime income principle for the calculation of pension benefits (instead of the best 15 or 20 income years as previously) will tend to reduce pension benefits given, for a large share of workers, their upward sloping age-earnings profiles. We may also expect that in countries with strong seniority-based wage system such as France, this reform will affect the pension replacement rates more than in countries with low wage seniority as for example in Sweden.

Extension of contribution periods will also have more severe gender equity implications where women are not continuous employees and where there are limited credits for childcare periods. On the other hand we may argue that intra-generational fairness might have played an important role in some countries like Sweden since the old system based on the best income years like in France, Poland and Sweden favoured people with a shorter contribution history and/or steeper lifetime earning profiles.

Most of the pension reforms take into consideration to at least some extent the diversity in patterns of labour market integration over the life course and the uneven distribution of risks between various socio-economic groups by limiting the cost of necessary work interruptions linked to parenting, care activities, or involuntary employment disruptions such as unemployment, disability or sickness. In order to limit the impact of these career interruptions on pension level several countries have introduced some income compensating mechanism in the calculation of pension benefits, although these are not necessarily sufficient to offset the extensions of contribution years. Indeed the extent, generosity and the type of interruptions across the life course covered by the pension system vary across countries. In Sweden, by far the most comprehensive and generous in this regard, the time that workers devote to higher education, to small children or to national military service, as well as absence due to unemployment and sickness, also gives rise to pension rights. In other words, future entitlements to a pension in Sweden are currently not only related to work history and earnings but are also linked to other forms of activity across the life course and periods of benefit receipt, including parental, unemployment, sickness and partial disability benefits.

In most countries, however, improvements in the calculation of benefits related to family commitments such as better upgrading factors and longer child-raising periods have been introduced (France, Germany and the $\mathrm{UK}^{4}$ ). On the other hand, female part-time work related to family commitments is seldom subsidized except in Sweden and more recently in Germany through the parental leave system. Where pensions are based on defined

\footnotetext{
${ }^{4}$ In the UK contribution years will be reduced to 30 , with more credits for caring activities, thereby increasing the share of women who qualify for a full state pension in their own right.
} 
contribution rather than defined benefits systems those earning lower wages due to parttime working in the early stages of pension accumulation will suffer significant disadvantages.

Table 5: Old age pension gross and net replacement rates at average earnings (mandatory pension schemes) and proportion of men and women aged 65 years and older at risk of poverty* 2008

\begin{tabular}{lcccc}
\hline & $\begin{array}{c}\text { Gross } \\
\text { replacement }\end{array}$ & $\begin{array}{c}\text { Net } \\
\text { replacement }\end{array}$ & $\begin{array}{c}\text { Risk of } \\
\text { poverty } \\
\text { Women }\end{array}$ & $\begin{array}{c}\text { Risk of } \\
\text { poverty Men }\end{array}$ \\
\hline EU-25 & - & - & 21 & 16 \\
Denmark & 80.3 & 91.3 & 19 & 17 \\
France & 53.3 & 65.7 & 18 & 12 \\
Germany & 43.0 & 61.3 & 12 & 10 \\
Italy & 67.9 & 74.8 & 24 & 17 \\
Netherlands & 88.3 & 103.2 & 9 & 10 \\
Poland & 69.6 & 74.9 & 13 & 9 \\
Sweden & 61.5 & 64.1 & 21 & 10 \\
UK & 30.8 & 40.9 & 33 & 28 \\
\hline
\end{tabular}

*At risk of poverty: Percentage of persons with and eqvivalised disposable income below the risk of poverty threshold which is set at $60 \%$ of the national median eqvivalised disposable income after social transfers.

Source: Society at a Glance: OECD Social Indicators, 2009 Edition

(www.oecd.org/els/social/indicators/SAG) and Eurostat 2008 for risk of poverty.

For many women, lower pay, fragmented work career and/or long period of part-time imply strong income penalties during retirement. In Italy but also in the UK elderly women are especially at risk of poverty ${ }^{5}$ (see Table 5) making women dependent directly on their husbands' and/or derived pensions (such as survivor pension). Benefits derived from marriage, however, are becoming even more uncertain owing to the increasing diversity of living arrangements. At the same time derived pension benefits have in some countries been continuously reduced or even suppressed (Sweden).

Furthermore, there remains a considerable gender divide over who has or who does not have a significant occupational pension. This relates to women's interrupted careers and to lack of provision and uptake among those in part-time jobs. With the exception of Sweden, married women still remain strongly reliant on derived rights to statutory or occupational pensions and this dependency in some countries, like the UK, has been increasingly extended to cohabiting couples or same sex couples, instead of a move towards more general individualised pension system as in Sweden. The decline in state pensions and the inadequate coverage of women has been and will be a major source of inequality and poverty in the future in many of our selected countries. Thus there is a risk that the progressive substitution of the statutory pension scheme through occupational or private pension schemes in some countries will further increase the still existing gender inequalities.

\footnotetext{
${ }^{5}$ In Italy, lower social security contributions, due to lower pay and fragmented work careers add up to an average pension that is only slightly more than half the average male pension (Anxo et al., 2010).
} 
More globally, the interaction between the increasing precariousness in employment (the rise of atypical employment and the increase of unemployment risks) and the stronger link between pension entitlements and work history make it more difficult for atypical workers (low-skilled, immigrants etc.) to provide for a decent pension at retirement.

\section{Restricting alternative exit routes: keeping 'all' older workers in employment?}

One of the major difficulties faced by the reforms of pension systems is to limit alternative early exit routes. Configurations of social protection systems and employment policies have a direct bearing on the departure paths open to older workers and largely shape the behaviours observed on the labour market. Countries adopt different balances between the three main modes of exits: unemployment, sickness leave or disability pensions, early retirement. International comparison of employment exit systems reveals a complex overlap of inter-permeable departure modes, impacted to varying degrees by changing institutional contexts and factors linked to the labour market. Where effective retirement ages are lower than the legal age of retirement, there is a tendency to use alternative paths of early departure are lower than the legal age of retirement. The rules governing the eligibility to these various schemes have been largely modified; the very existence of these schemes has been called into question. These changes have occurred at different periods and there is sometimes a move back to provisions favouring early exit. In Germany, early exit provisions have been reduced progressively, including a strong decrease in the duration of the maximum entitlement to unemployment compensation for older workers in 2005. However, this duration has been increased in 2008. The Netherlands has during the last years considerably restricted the use of disability leave as an instrument of early exit from the labour market (Schippers et al., 2011). In France, the duration of unemployment compensation for older workers has been lowered in 2002 and the age at which one can benefit from a non-decreasing unemployment compensation until retirement have been increased (Guillemard and Jolivet, 2011). In Poland, the options for early retirement in the mandatory pension system were eliminated by the 1999 pension reform. The criteria to receive disability pensions were tightened. Specific schemes allowing early retirement without penalties for some occupational groups have been replaced by one system of bridging pensions, but most occupational privileges remain. In Sweden also reforms of unemployment insurance and disability pension have restricted the use of this channels for early exit from the labour force for older workers while early exit for labour market reason has, since the 1990s, been banned (Anxo and Ericsson, 2011).

The combined effect of reducing alternative exit routes through the social protection systems and raising the legal age of retirement leads to the conclusion that sustainable health and work-capacities are crucial for the success of obtaining longer working-life. The 2004 survey on health, ageing and retirement in Europe (SHARE conducted in ten European countries) has shown that the state of health and work-satisfaction affect the desire to go on retirement (Blanchet and Debrand, 2005). On average, the probability of wanting to retire earlier falls by 14,2 percentage points for persons who are satisfied with their jobs; and by 5,5 points for persons who said their health was good. On the contrary, hard working conditions (physically hard, under pressure, heavy workloads, and a lack of freedom in the performance of one's job) increase from 4 to 6 points the probability of 
wanting to retire early. Problems of health after the age of 50 are not to be overlooked. Health conditions that negatively affect everyday activities increase with age, from a few percent of the population below the age of 20 to more than $50 \%$ after the age of 75 ; but the differences are wide between countries in Europe, as shown in the 2005-2007 SILC survey (Statistics on income and living conditions ${ }^{6}$ ). The number of healthy years of life ${ }^{7}$ varied more among these countries than life expectancy, in particular for the 55-74 agegroup. Denmark, Netherlands, Sweden and the United Kingdom had both more than the average number of healthy years of life and the average duration of life expectancy in good self-perceived health. France and Italy showed lower number of healthy years of life and duration of life expectancy in good self perceived health than this group of countries. On the contrary, Poland was among the countries with the lowest level for two three indicators and for the duration of life expectancy. Germany was close to countries with the average life expectancy but second lowest years in life expectancy in good self perceived health (Jagger et al., 2010).

In addition, differences by age also exist between European countries with regard to working conditions, which help to explain differences in senior employment rates (Mardon and Volkoff, 2011). In the countries where senior employment rates are high, physically hard postures are less frequent (at all ages and, in particular, for persons over 45), night work is rare (at all ages and, in particular, for persons over 45), and there are many more opportunities for learning throughout the career. The exposure to time pressure is rather high, but older workers are relatively less exposed than young people. This is the case in Denmark, Sweden and the United Kingdom.

There is an obvious risk that larger groups of older workers will leave the labour force, not due to economic incentives, but because their health status and working conditions do not enable them to compete with younger generations. This creates a political pressure to re-introduce social protection systems that support early retirement or to improve the way health status or working pathways are in taken into account. Consequently, the central stake is to maintain or even develop the "capacities" throughout life, via training (by taking account the different methods of training according to age and experience), changing jobs and mobility (including at the end of the career), the prevention of incapacity and health problems, and a reflexion on the conditions and organisation of work (by offering or maintaining room for manoeuvre, by giving meaning to work and the possibility to learn while working). This is promoted by a «sustainable work» analysis. A second stake is to improve the recruitment of older jobless workers.

\section{Less initiative left to employers?}

The recent increases in retirement/entitlement ages and changes in eligibility criteria have often been combined with a stronger individual right to "decide" at what age to receive pension benefits and when to retire from the labour force. Mandatory retirement is gradually abolished as a generally accepted norm that governs both employers' and employees' retirement decisions. Instead, the initiative to retire has been shifted from the employers to the employees. For example in France, the age at which an employer can force an employee to retire has been raised to 70 (67 under certain conditions since the 2010 pension reform). Employees may claim a full pension from the age of 62 . This

\footnotetext{
${ }^{6}$ See www.ehemu.eu.

${ }^{7}$ Healthy Life Years (HLY), life expectancy without long-term activity limitations, is a structural indicator since 2004 .
} 
means that employees in the age bracket 62-70 are, in theory, free to decide whenever to draw pension benefits and whenever to leave their jobs, while their employers have smaller options to influence their retirement decisions.

There are various national regulations for employers' right to induce older employee to leave their job. In some cases, regulations increase employment protection for older wage-earners or even forbid dismissals after a certain age. In Poland, since 2004 an employer may not dismiss an employee during the four years preceding the standard retirement age. In other countries, age-based provisions that have been protecting older employees are removed (Netherlands, France). In Sweden, existing regulations ending at the age 67 have been maintained. Other countries have changed regulations about fixedterm employment contracts. Germany opened the possibility of fixed-term employment contracts for older workers in 2001. Since 2003, the age requirements have been lowered; and employers who hire persons over the age of 55 years do not have to contribute to the old-age insurance fund.

This development raise questions about older workers' general positions in jobs and on the labour market. As employers will have less formal influence on which employee they want to keep and who they want to retire, it is possible that discrimination of older workers will increase ${ }^{8}$. In short, if employers are less informed about when older employees will retire and how productive they will be, then it could be perceived as less risky for employers to recruit younger workers instead.

Under pressure from the EU directives of 2000, laws prohibiting age-based discrimination have been adopted. Discrimination towards older workers, either due to stereotypes or to indirect discrimination (statistical discrimination), may explain their difficulties on the labour market. The prohibition of age-based discrimination has led to modifying certain legal provisions (for instance, about mandatory retirement, or, in France, about recruitment to the civil service). Anti-discrimination rules have mainly a cognitive effect. In some cases, the fear of judiciary actions leads to systematically exclude age-segmented initiatives (as in United Kingdom). However there is little evidence of a general positive impact on perceptions towards age. A comparison between Denmark and Sweden shows for example that employers are more reluctant to hire older workers in Sweden than in Denmark (Anxo et al., 2011; Jensen and Madsen, 2011), even if age discrimination is prohibited in both countries.

\section{Impact on unpaid activities}

The lengthening of working life often raises concerns about older peoples' reduced time for voluntary work and participation in associative activities. This fear rests on the assumption that paid work will substitute unpaid work in voluntary organisations. However, one should not neglect possibilities to combine employment with associative activities. Some companies favour participation in associations, in the course of career but more especially at the end of the career. The opportunities to reduce working time before and after retirement might limit the substitution effect between employment and unpaid activities.

\footnotetext{
${ }^{8}$ Another answer could be to find side-ways to incent older people to retire as soon as they are entitled to a full pension.
} 
Regarding household activities, it is often the case that senior workers experience a growing responsibility for dependent relatives. Two questions then arise. Will an effective postponement of the retirement age reduce the time devoted to caring activities provided by family members and worsen in certain countries the current 'care deficit'? To which extent can individuals who assume these caring tasks be able to reconcile paid and unpaid activities?

Even if the provision of both formal and informal eldercare varies significantly across our countries, inequalities remain very important between men and women. Elderly care remains highly gendered. Women are the main providers of elderly care on an informal basis within the family or as neighbours, as well as employees in formal services As stressed in Anxo and Fagan (2005) and Simonazzi (2009), in the Mediterranean countries but also in France and Poland, families are still legally bound to take care of elderly people; in continental Europe family responsibilities are regulated implicitly, while in Denmark, the Netherlands, the UK and Sweden there is no family obligation stipulated by law and the entitlement to a minimum level of service is universal and individualized. European countries might be classified into two main clusters according to the prevalence of formal or informal care markets. As pointed out by Simonazzi (2009), the various care regimes differ in their ability to create a care market, either social, i.e. with a strong public governance, or private. Countries like Sweden (relying on in-kind provision with strong public governance), the UK (relying on a public funded system but based on contracting the supply to services to the private sector) or France (relying on in cash allowance through the system of "cheque service"), belong to the first cluster, i.e a formal care market regime. Systems relying mainly on unconditional cash assistance or monetary transfers, such as the continental (Germany) and Mediterranean countries, fall within the informal or mixed categories depending on the extent of public funding.

There is a clear correlation between female employment rates and the extent of formal market care regimes. Those countries having opted for a high provision of formal services have the highest overall female employment rates while the familialistic Mediterranean countries that have promoted the provision of informal/family carers display the lowest female employment rates. This can be explained by the direct positive effect of the creation of a formal care market on female employment, since the care sector remains a clear female dominated sector and indirectly since the negative impact of informal care giving on female labour supply at the extensive (labour force participation) and intensive margins (working hours given participation) can be expected to be lower in countries characterised by highly institutionalised systems and a high provision of eldercare. This seems confirmed by a recent study (Kotsadam, 2009) that found that the negative impact on female labour supply of time spent on informal eldercare is significantly higher in countries with a weak formal care market and more pronounced gendered care norms; that is for instance in the Mediterranean countries compared to the Scandinavian countries.

Surveys highlight triple, even quadruple days, for the women who work and deal with their old relatives (Le Bihan-Youinou and Martin, 2006). Unlike parental work, there is generally no trade-off between assistance to dependent parents and continuation of a professional activity, particularly if we consider that the needs for assistance of the dependent parents can vary very quickly, in a very unforeseeable way, and with a very variable width. Trade-offs are then often individual, and are made to the detriment of personal life, leisure, holidays, friendly and family social life. 


\section{Conclusion}

Demographic ageing and longer life expectancy raise challenges that cannot be reduced to the long run financial sustainability of pension systems. Specific questions will arise with more acuity if/when the effective retirement is being postponed. Assistance to dependent relatives calls for the introduction of adapted policy measures aiming at reconciliating paid work and care activities. The prevailing incentives to postpone the retirement decision pave the way for an increasing uncertainty on the effective age of retirement, entailing a possible larger dispersion of the exit age. This calls for increasing awareness of discrimination of older workers and of the challenge of sustainable work among policy makers, especially for lower educated workers.

In our view, the best way of prolonging working life is to enhance diversity of choices concerning employment patterns at the end of the job career, such as for example progressive retirement, self-employment, etc (Pengcharoen \& Shultz, 2010). Against this background, it is also crucial to limit the potential negative consequences of these choices on the level of pension benefits, on social protection and employment regulation, such as employment protection. Last but not least, it should be stressed that a too strong focus on targeted measures toward senior workers may also run up against a logic of age diversity at the company level, and even constitute an obstacle to a preventive approach of active ageing. 


\section{References}

Alexandrowicz, P. and Frerichs, F. (2011), "Senior Workers' Participation in the Labour Market and Public Policies: The case of Germany", Anxo, D. ,Guillemard, A.-M., Ericson, T. and Jolivet, A. (eds), Transitions from Work to Retirement : Still a Maximum Diversity in a Minimum of Space, ASPA project, report for the European Commission, Brussels.

Anxo, D., Bosch, G. and Rubery, J. eds (2010), The welfare State and Life Transitions: A European Perspective, Edward Elgard, Cheltenham, UK.

Anxo, D. and Ericsson, T. ( 2011), “"Senior Workers' Participation in the Labour Market and Public Policies: The case of Sweden", Anxo, D., Guillemard, A.-M., Ericson, T. and Jolivet, A. (eds), Transitions from Work to Retirement : Still a Maximum Diversity in a Minimum of Space, ASPA project, report for the European Commission, Brussels.

Anxo, D., Guillemard, A.-M., Ericson, T. and Jolivet, A. (2011), Transitions from Work to Retirement : Still a Maximum Diversity in a Minimum of Space, ASPA project, report for the European Commission, 30 June, Brussels.

Anxo, D. and Erhel, C. (2008), “Irréversibilité du temps, réversibilité des choix? Les fondements des 'marchés transitionnels' en termes de trajectoires de vie", Revue Française de Socio-Economie, n ${ }^{\circ}$, pp. 199-219.

Anxo, D., Fagan, C., Cebrian, I. and Moreno, G. (2006), "Patterns of labour market integration in Europe: a life course perspective on time policies", Socio-Economic Review, 5 (2), pp. 233-260.

Anxo, D. and Fagan, C. (2005), "The Family, the state and now the market: The organisation of employment and working time in the home care services", Bosch, G. and Lehndorff, S. (eds), Working in the Service sector. A tale from different world, Routledge, London and New York.

Blanchet, D. and Debrand, T. (2005), "Aspiration à la retraite, santé et satisfaction au travail: une comparaison européenne", INSÉÉ Première, 1052.

Checcucci, P., Di Rosa M., Lamura G. and Principi A. (2011), "Senior Workers' Participation in the Labour Market and Public Policies: The case of Italy ", Anxo, D., Guillemard, A.-M., Ericson, T. and Jolivet, A. (eds), Transitions from Work to Retirement : Still a Maximum Diversity in a Minimum of Space, ASPA project, report for the European Commission, Brussels.

Casey and Lindley R. (2011), "Older Worker Labour Force Participation and Policy in the UK", Anxo, D., Guillemard, A.-M., Ericson, T. and Jolivet, A. (eds), Transitions from Work to Retirement: Still a Maximum Diversity in a Minimum of Space, ASPA project, report for the European Commission, Brussels.

Cornilleau, G., $\quad$ Sterdyniak, H., $\quad$ Allegre, G., $\quad$ Creel, J., Guillou, S., $\quad$ Levasseur, S., Mathieu, C., Reynes, F., Stancanelli, E. and Touze, V. (2007), Étude comparative sur les pays européens ayant un taux d'emploi des seniors élevé, OFCE, report to the Conseil 
d'Orientation des Retraites, September, http://www.cor-retraites.fr/IMG/pdf/doc1203.pdf.

Guillemard, A.-M. (2010), Les défis du vieillissement, Age, Emploi, Retraite, Perspectives internationales, Armand Colin, Paris.

Guillemard, A.-M. and Jolivet, A. (2011), "France: Struggling to find a way out of the early exit culture", Anxo, D., Guillemard, A.-M., Ericson, T. and Jolivet, A. (eds), Transitions from Work to Retirement : Still a Maximum Diversity in a Minimum of Space, ASPA project, report for the European Commission, Brussels.

Jagger, C., Gillies, C., Cambois, E., Van Oyen, H., Nusselder, W., Doblhammer, G., Rychtarikova, J., Robine, J.M. and the EHLEIS team (2010) "Similarities and differences in healthy life years across the lifecourse in Europe", paper submitted at the REVES Annual Meeting, Havana.

Jensen, P. H. and Madsen, P. T. (2011), "From Passive to Active Approaches in Danish Senior Policies", Anxo, D., Guillemard, A.-M., Ericson, T. and Jolivet, A. (eds), Transitions from Work to Retirement : Still a Maximum Diversity in a Minimum of Space, ASPA project, report for the European Commission, Brussels.

Kotsadam, A. (2009), The effects of informal eldercare on the female labor supply in different European welfare states, mimeo, Department of Economics, School of Business Economics and Law, Goteborg University.

Le Bihan-Youinou, B. and Martin, C. (2006), "Travailler et prendre soin d'un parent âgé dépendant", Travail, genre et sociétés, 2/2006, n 16, pp. 77-96.

Mardon, C. and Volkoff, S. (2011), "Emploi des 'seniors' et conditions de travail: une étude statistique comparative entre pays d'Europe", Pistes, 13(1), May, http://www.pistes.uqam.ca/v13n1/articles/v13n1a6.htm.

OECD (2003), "Retirement behaviour in OECD countries: impact of old-age pension schemes and other social transfer programmes", OECD Economic Studies, No. 37, $2003 / 2$.

OECD (2008), "Reforming retirement-income systems: lessons from the recent experiences of OECD countries", OECD Social, Employment and Migration Working papers, No. 66.

OECD (2009a), Pensions at glance 2009, OECD, Paris.

OECD (2009b), Statistics on Effective Age of Retirement, Paris: OECD, http:// www.oecd.org/document/47/0,3343,en_2649_34747_39371887_1_1_1_37419,00.html, accessed October 2010.

Pengcharoen, C., K.S. Shultz (2010), The influences on bridge employment decisions, International Journal of Manpower, 31(3): 322-336.

Perek-Bialas, J. and Turek, K. (2011), "Senior Workers' Participation in the Labour Market and Public Policies: The case of Poland ", Anxo, D., Guillemard, A.-M., Ericson, 
T. and Jolivet, A. (eds), Transitions from Work to Retirement : Still a Maximum Diversity in a Minimum of Space, ASPA project, report for the European Commission, Brussels.

Schippers, J., Conen, W. and Henkens, K. (2011), "Senior Workers' Participation in the Labour Market and Public Policies: The case of the Netherlands", Anxo, D., Guillemard, A.-M., Ericson, T. and Jolivet, A. (eds), Transitions from Work to Retirement : Still a Maximum Diversity in a Minimum of Space, ASPA project, report for the European Commission.

Simonazzi, A-M (2009), "Care Regimes and National Employment Models", Cambridge Journal of Economics, 33(2), pp. 211-232.

Dalen, H.P. van, K. Henkens, W. Hendrikse \& J.J. Schippers (2010), Do European employers support later retirement? International Journal of Manpower 31 (3): 360-373. 
